\title{
Correction: Marques, A. et al. Evolution of Plant B Chromosome Enriched Sequences. Genes 2018, 9, 515
}

\author{
André Marques ${ }^{1, *}$, Sonja Klemme ${ }^{2}\left(\mathbb{D}\right.$ and Andreas Houben ${ }^{3}[\mathbb{C}$ \\ 1 Laboratory of Genetic Resources, Federal University of Alagoas, Av. Manoel Severino Barbosa, \\ 57309-005 Arapiraca-AL, Brazil \\ 2 Biology Centre, Czech Academy of Sciences, Institute of Plant Molecular Biology, Branišovská 31, \\ CZ-37005 České Budějovice, Czech Republic; sonja.klemme@gmx.de \\ 3 Leibniz Institute of Plant Genetics and Crop Plant Research (IPK), Corrensstrasse 3, \\ 06466 Gatersleben, Germany; houben@ipk-gatersleben.de \\ * Correspondence: andre.marques@arapiraca.ufal.br
}

The authors wish to make the following modification in their review [1]. Change Eyprepocnemis plorans to Locusta migratoria and Eyprepocnemis monticola to Eumigus monticola in the following paragraph:

"With the RepeatExplorer and RepeatMasker programs, the satellite DNA composition of the migratory locust (Locusta migratoria) B chromosomes was determined [19]. The 'satellitome' in the grasshopper Eumigus monticola consists of 27 satellite DNAs [6], less than half of the migratory locust, where 62 were found [19]."

The changes do not affect the scientific results. The manuscript will be updated, and the original will remain online on the article webpage, with a reference to this Correction.

\section{Reference}

1. Marques, A.; Klemme, S.; Houben, A. Evolution of plant B chromosome enriched sequences. Genes 2018, 9, 515. [CrossRef] [PubMed]

(C) 2019 by the authors. Licensee MDPI, Basel, Switzerland. This article is an open access article distributed under the terms and conditions of the Creative Commons Attribution (CC BY) license (http:/ / creativecommons.org/licenses/by/4.0/). 